DOI https://doi.org/10.30525/978-9934-588-79-2-1.13

\title{
ОРГАНІЗАЦІЯ ПОСИЛЕННЯ КОМУНІКАЦІЙНИХ ЗВ'ЯЗКІВ У ВЕБ-СПІЛЬНОТАХ
}

\author{
Марковець О. В. \\ кандидат технічних наук, \\ дочент кафедри сочиіальних комунікацій та інформачійної діяльності \\ Національного університету «Львівська політехніка» \\ м. Львів, Україна
}

Соціалізація сервісів нового покоління, знаходить своє відображення в тому, як активно користувачі сервісів беруть участь в обговореннях різного роду інформації, залишають свої коментарі, ведуть дискусії та спілкуються один $з$ одним, слідкують за останніми новинами, що розміщують на сайтах мережі Інтернет. Тому, як наслідок, 3 груп користувачів Веб-сайтів утворюються веб-спільноти.

Сьогодні веб-спільноти охоплюють різні сфери життя. Їх кількість учасників щодня збільшується. На шляху розвитку веб-спільнот виникає проблема їх ефективного функціонування, що не дозволяє їм реалізувати свій потенціал щодо накопичення та трансферу знань, вирішити яку допоможе ком'юніті-менеджмент - новий вид діяльності, що сприяє підвищенню комунікаційних зв'язків та розвитку спільноти.

Перші спеціалісти такого профілю виникли у компаніях власниках масштабних онлайн-ігор. Це допомогло краще розуміти спільноту та iii потреби, залагоджувати конфлікти і одержувати зворотний зв'язок для корегування планів подальшого розвитку ігрових віртуальних середовищ.

Ком'юніті-менеджер - це носій ідеї та ідеології свого бренду, компанії, з якими він співпрацює. Він відповідає за формування (або виявлення) лояльних до бренду людей, спілкування з ними, втягнення ïx у спілкування навколо бренду. Поняття «ком'юніті-менеджер» виходить за рамки наявних знань і досвіду використання соціальних мереж, це не фахівець з реклами в соціальних мережах, а управлінець спільнотами.

Специфіку діяльності ком'юніті-менеджера, найбільш повно відображають його ролі: 
- Адвокат. Займається представленням інтересів клієнтів. Цей процес включає моніторинг, аналіз та інтерпретацію думок клієнтів, винесення актуальних проблем за межі спільноти (наприклад на офіційний рівень).

- Свангеліст. Здійснює промоцію думок та настроїв клієнтів, рекламу подій, продуктів і оновлень (компанії, бренду, організації).

- Комунікатор. Спонукає спільноту до ведення обговорень, спрямовує їх у потрібне русло. $€$ посередником у конфліктах всередині спільноти, а також розробляє та застосовує певну тактику ведення дискусій.

- Футурист. Футурист збирає, організовує і представляє зацікавленим сторонам пропозиції спільноти та знання про іiі бачення майбутнього.

В залежності від сфери у якій працює цей фахівець до нього висуваються різні вимоги, у відповідності до яких ком'юніті-менеджер виконує вище розглянуті ролі, які є багатофункціональними [1].

Спектр обов'язків, що можуть спричинити за собою певну роль ком'юніті-менеджера:

- Створення контенту - написання повідомлень, статей, інформаційних бюлетенів, комунікаційних матеріалів та інших видів інформаційного наповнення.

- Управління контентом - управління змістом інформаційного наповнення, сприяння створенню високоякісних матеріалів.

- Утримання існуючих та залучення нових учасників.

- Підвищення активності учасників - створення опитувань, спонукання учасників до створення інформаційного наповнення, ведення дискусій, а також реагувань на дії інших учасників.

- Маркетинг в соціальних мережах - залучення трафіку користувачів та привернення уваги до спільноти через соціальні платформи.

- Офф-лайн присутність - організація заходів та зустрічей для активних учасників спільноти.

- Відносини з учасниками спільноти - надання відповідей на запитання, керування відгуками.

- Реалізація - сприяння реалізації стратегії спільноти, для ефективного ऑї функціонування.

- Поширення - розміщення інформаційного наповнення на кількох майданчиках (кроспостинг). 
- Адвокація - представлення інтересів спільноти (моніторинг, аналіз та інтерпретація думок учасників спільноти).

- Управління користувачами - реєстрація користувачів, управління діями користувачів.

Спектр обов'язків ком'юніті-менеджера може бути розширений взалежності від цілей та потреб спільноти [2].

Ефективність роботи ком'юніті-менеджера, виходячи 3 його функцій, можна оцінювати за такими критеріями:

- кількісними показниками приросту користувацького інформаційного наповнення спільноти;

- кількістю реакцій користувачів на це наповнення («лайки», поширення інформаціі);

- динамікою приросту та відтоку учасників спільноти;

- кількістю конверсій (для цілеспрямованих спільнот, зокрема для спільнот із комерційною складовою).

Ком'юніті-менеджмент включає в себе можливість підтримки спільнот на всіх майданчиках Вебу. Основну відповідальність за забезпечення постійного функціонування спільнот та активну взаємодію 3 iї учасниками несе ком'юніті-менеджер.

\section{Література:}

1. Perkins Lauren. The Community Manager's Playbook: How to Build Brand Awareness and Customer Engagement / Lauren Perkins. Apress, 2014. - $316 \mathrm{c}$.

2. Social media community manager playbook [Електронний pecypc]. - Електрон. дані. - Режим доступу: http://cdn2.hubspot.net/ hub/74005/file-15566531-pdf/docs/lyntonweb-social-media-communitymanager-playbook 